\title{
The Hutchinsonian defence of an Old testament Trinitarian Christianity: the controversy over Elahim, 1735-1773
}

\author{
Derya Gurses \\ Department of History, I.I.S.B.F., Bilkent University, 06800 Ankara, Turkey
}

\begin{abstract}
The importance of Hebraic studies as part of the eighteenth-century Enlightenment debate can hardly be overestimated. The question of the authority of the Books of Scripture forced intellectuals in England to revisit the language of the Old Testament text. The agenda of the Hutchinsonians here was to highlight the Old Testament's Trinitarian elements, as they saw them. The controversy over the etymology of the word Elahim illustrated that the Hutchinsonians were the young Turks of orthodoxy in the fight between fideism and rationalism. It also demonstrated the problem the Hutchinsonians represented for those who would otherwise be their Trinitarian allies.
\end{abstract}

(C) 2003 Elsevier Ltd. All rights reserved.

\section{Introduction}

Recent scholarship has focused on the preoccupation of eighteenth-century Western thought with the Old Testament text. Some scholars even argue that the rationalist early Enlightenment had as its principal subjects the Jewish religion and its text. ${ }^{1}$ The same argument has been made for the fideistic wing of Enlightenment thought. ${ }^{2}$ A view of the Enlightenment that embraces both fideist/orthodox and

\footnotetext{
E-mail address: gderya@bilkent.edu.tr (D. Gurses).

${ }^{1}$ See for example, A. Sutcliffe, Judaism and Enlightenment (Cambridge University Press, 2003). See also J. Israel, Radical Enlightenment, Philosophy and the Making of Modernity, 1650-1750 (Oxford University Press, 2002) for his putting Spinozism at the heart of the Enlightenment debate. Israel argues that Spinoza's preoccupation with the Old Testament to question revelation and divine providence influenced the intellectual history of the eighteenth century.

${ }^{2}$ See D.B. Ruderman, Jewish Enlightenment in an English Key, Anglo-Jewry's Construction of Modern Jewish Thought (Princeton and Oxford: Princeton University Press, 2000), pp. $23-57$.
} 
rationalist wings of eighteenth-century thought will be adopted throughout this paper. The reason for such a choice is that both parties were inspired by certain currents of thought like sensationalism, a particular interest in natural philosophy and the comparative history of religion, and last but not least a considerable interest in biblical hermeneutics. Questions over the authority of the Bible kept Newtonians, Hutchinsonians, Methodists, Non-Jurors and Unitarians occupied for the whole of the century and the Old Testament was at centre-stage. As far as Hebraic studies are concerned, a view of eighteenth-century English thought which puts religious questions into the spotlight makes it possible to see systems like Hutchinsonianism, which have been presented as singularities, as part of a wider whole. In the eighteenth-century intellectual context, Hutchinsonians represented a group who tried to support a Trinitarian Protestant Christianity from the Old Testament. The attempt made by the Hutchinsonians can be seen as a redefinition of Protestant identity, making use of a reassessment of Enlightenment epistemology, a form of Hermetic Cabbala and the reinstatement of the authority of the Book in a proper Protestant fashion.

The study of Hutchinsonianism is long established, but not extensive. David Katz points out that 'the influence [of] the Hutchinsonians was enormous in the eighteenth century, ${ }^{3}$ yet no full-scale study of the movement has been undertaken. We have, at best, only articles and extended comments in works dealing with other subjects. The historiography, while not entirely neglecting an interdisciplinary approach, has tended to overemphasize either an approach to the history of science ${ }^{4}$ or, less commonly, a perspective drawn from the history of religion. ${ }^{5}$ The authors are not necessarily to be faulted for this, in view of the brevity of their works, but a more complete study may achieve a better balance. In particular, one needs to recognize the fluidity of the boundaries between religion, politics and science in the eighteenth century.

Hutchinsonianism, the eighteenth-century movement founded by John Hutchinson (1674-1737), was actively promoted throughout almost the entire eighteenth century. The movement had its foundations in its rejection of rationalist Enlightenment thought in the areas of cosmology and theory of knowledge. The feature of Enlightenment thought to which Hutchinsonians particularly objected was the departure from divine analogy in matters of cosmology. In other words,

\footnotetext{
${ }^{3}$ D.S. Katz, 'Moses's Principia: Hutchinsonianism and Newton's Critics', in J.E. Force and R.H. Popkin (Eds.), The Books of Nature and Scripture: Recent Essays on Natural Philosophy, Theology and Biblical Criticism in the Netherlands of Spinoza's Time and the British Isles of Newton's Time (Dortrecht: Kluwer, 1994), pp. 210-213.

${ }^{4}$ See, for example, A.J. Kuhn, 'Glory or Gravity: Hbutchinson vs. Newton', Journal of the History of Ideas, 22 (July-September 1961): pp. 303-22; M. Neve and R. Porter, 'Alexander Catcott: Glory and Geology' The British Journal for the History of Science, ix (1977): pp. 37-60. C.B. Wilde, 'Hutchinsonianism, Natural Philosophy and Religious Controversy in Eighteenth-Century Britain' History of Science, 18 (1980): pp. 1-24.

${ }^{5}$ C.D.A. Leighton, 'Hutchinsonianism: A Counter-Enlightenment Reform Movement' Journal of Religious History, v. 23, n. 2 (June, 1999): pp. 168-84; 'Knowledge of Divine Things: A Study on Hutchinsonianism', History of European Ideas 26 (2001): pp. 159-75, B.W. Young, Religion and Enlightenment in Eighteenth-Century England (New York: Oxford University Press, 1998), pp. 120-63.
} 
Hutchinsonians were against cosmological speculation without the aid of, what they saw as, Trinitarian analogy from scripture. Like many other Trinitarian Christians, the Hutchinsonians viewed the century in which they lived as a period of an assault on Trinitarian Christianity, and specifically on a Trinitarianism based on revelation. The backbone of Hutchinsonian belief was its defence of the Trinity in matters of cosmology and religious speculation. The Anti-Trinitarian plot had to be resisted, and for this Hutchinson's system was a valuable tool, providing a freedom of manoeuvre whereby thinkers and polemicists could switch from cosmology to biblical exegesis, from a critique of rationalist Enlightenment thought in matters of natural philosophy to a defence of the Eucharist.

Hutchinson's early followers differed in what they preferred to emphasize within these large issues. Alexander Stopford Catcott, for example, as we shall see, concentrated on the study of the etymology of the Hebrew word Elahim. Duncan Forbes of Culloden chose as his mission the popularization of Hutchinson's thought in an understandable way by publishing explications of it with a special emphasis on cosmology and the religious speculation related to it. Benjamin Holloway preferred an overall approach, using both the New and the Old Testaments to underline Hutchinsonian concerns. Robert Spearman and Julius Bate were the active missionaries of the movement and their publications remained the central presentation of Hutchinson's system of thought through all its stages. All these followers argued for a conception of a self-sufficient universe where all the operations in nature were performed by the triune agents - fire, light and spirit. This Trinitarian covenant, they argued, maintained the theoretical reliability of the Genesis account and signified the nature of the deity.

The Deist literature of the eighteenth century took as its favourite subject the lack of congruence between the New Testament and the Old Testament prophecies. 'The uniqueness of Judaic monotheism' ${ }^{6}$ was an essential tenet for Hutchinsonians, whereas the Deist literature, provided by individuals such as Herbert of Cherbury, questioned this as well as promoting the universality of natural religion through a comparative history of religion. ${ }^{7}$ The likes of Anthony Collins, William Whiston and Matthew Tindal rejected the analogical method used to relate the two books as a continuing revelation. The early Hutchinsonian defence of this method was bolstered by their Hebraic studies and this caused a lot of reaction from Christian Hebraists at the time.

The Hutchinsonian method of interpreting the Old Testament attracted interest in the movement among academic circles, such as at Oxford; even new followers who were to carry Hutchinsonian interests into the nineteenth century took up an interest in Hebrew as their initial Hutchinsonian undertaking. Here I will introduce the longlasting controversy that highlights the use of the Old Testament text to provide a defence of the Trinity.

\footnotetext{
${ }^{6}$ F. Manuel, The Broken Staff, Judaism Through Christian Eyes (Cambridge, MA: Harvard University Press), p. 176.

${ }^{7}$ See Ibid., pp. ${ }^{174-91}$ for the profiles of eighteenth-century English Deists in this matter.
} 
Hebrew studies were a central concern of the Oxford Hutchinsonians in the middle years of the eighteenth century. They produced some 18 pamphlets on Hebraic studies between 1750 and 1767 . Some of these works were the lexicons, grammars and dictionaries prepared by Julius Bate, Samuel Pike, William Romaine and John Parkhurst. $^{8}$ The best of these was probably the Hebrew-Latin Lexicon prepared by Parkhurst, which was patronized by Horne after he was made a bishop. ${ }^{9}$ Jones of Nayland, in a letter written to Catcott junior on 23 January 1762 stated his pleasure on reading this work: 'Have you seen Mr. Parkhurst's book? It is the fruit of great reading and indefatigable attention, and is the only work I ever saw, under the name of a Lexicon, that will bear reading for amusement'. ${ }^{10}$

The Elahim Controversy is important in many respects. It shows that the Hutchinsonians were a part of an 'early Enlightenment' debate on the status and language of the Old Testament and that their methods provoked a considerable amount of interest if not universal agreement. Another point which should be pointed out is that Hutchinsonians were quite uncompromising about what they thought was the true method of dealing with the unpointed Hebrew text of the Old Testament. Their insistence on the monopoly of truth was to become a partial reason for their relative marginality. This intolerant behaviour manifested itself especially at the time the Controversy took place.

Hebraic studies endured as a Hutchinsonian preoccupation at least up until the late 1760s. George Watson, the person responsible for introducing Hutchinsonianism to both Jones of Nayland and Horne, was a Hebrew scholar at Oxford, and the teacher of both Jones of Nayland and Horne. How he himself was exposed to the ideas of Hutchinson is not clear, but Horne and Jones of Nayland certainly read Hutchinson under Watson's influence. This was recounted later by Jones of Nayland in his account of Horne's life: 'This gentleman, [Watson] with all his other qualifications was a Hebrew Scholar, and a favourer of Mr. Hutchinson's philosophy, but had kept to himself'. ${ }^{11}$ Jones of Nayland admitted that with the help of his Hebrew teacher, his interest in the language had flourished so much that 'I had nearly worked myself to death, by determining, like Dons Scotus in the Picture Gallery, to go through a whole chapter in the Hebrew one night'. ${ }^{12}$ It was Jones of Nayland who introduced Horne to Watson, and it turned out to be a very fruitful encounter since Horne, 'instead of going home to his friends in the vacation, stayed for the advantage of following his studies at Oxford, under the direction of his new teacher'. ${ }^{13}$ The acquaintance of Horne and Jones of Nayland with the Hutchinsonian Watson dates back to the 1730s. By then, the young students of Oxford, like

\footnotetext{
${ }^{8}$ Julius Bate, A Hebrew Grammar (London, 1751), John Parkhurst, Lexicon (London, 1762), Samuel Pike, Hebrew Lexicon (London, 1766), William Romaine (Ed.), Hebrew Dictionary and Concordance of F. Marius de Calasio (London, 1746).

${ }^{9}$ Jones of Nayland, Memoirs, p. 107.

${ }^{10}$ Catcott Correspondence, Bristol Reference Library, B 26063, f. 56, Jones of Nayland to Alexander Stopford Catcott, 23 January 1762.

${ }^{11}$ Jones of Nayland, Memoirs, p. 27.

${ }^{12}$ Ibid.

${ }^{13}$ Ibid.
} 
Horne and Jones of Nayland, already had established interests in Hebrew and cosmology. In this respect, Hutchinsonianism might have served well to provide an easily adaptable intellectual view for them even before the publication of The Works of Hutchinson in 1748, though this certainly stirred a second round of interest in academic circles, including at Oxford.

The controversy over Elahim began with Catcott's pamphlet The Supreme and Inferior Elahim which was published in $1736 .{ }^{14}$ The interpretation of the Old Testament word Elahim as the triune God, and the insistence on the unity of the Divinity and Humanity of Christ, were designed to secure the concept of the Trinity from Unitarian and other anti-Trinitarian threats. The Catcott debate continued throughout the 1750s with some changes in its nature and with the participation of Hebraists, pro- and anti-Hutchinsonian. The whole pamphlet war provides valuable information on the reception of Hutchinsonian thinking, and is important in the sense that it was the first time that Hutchinsonians had made their views public. It was also the one and only pamphlet war in which John Hutchinson himself was involved.

Catcott, with his pamphlet The Supreme and Inferior Elahim (1736), set out the Trinitarian agenda of early Hutchinsonians. Hebraic studies as a part of biblical exegesis provided an important tool for the defence of the Trinity. The word Elahim in the Old Testament was interpreted by Catcott as a plural noun so as to underline the promise of Trinitarian Christianity in the Old Testament text. Ruderman has pointed out that Hebraic studies were a distinguishing Hutchinsonian feature: 'Until the Hutchinsonians had reclaimed the study of Hebrew as their own, to be mastered through their own sacred methods, it was essentially a Jewish discipline'. ${ }^{15}$ Although one may want to dispute his argument, I still share Ruderman's view that it was a viable project to establish a novel and correct Hebrew text of the Old Testament for its own sake, and as a part of the effort to lay Christian claim to the Old Testament as revelation. ${ }^{16}$ In addition, it is particularly important to note that the long-standing debate between Hutchinsonians and other Christian Hebraists marks the difference between a group wanting to claim the Old Testament in order to enhance a Trinitarian Christian identity and those who thought the Hutchinsonians went too far in searching for explicit Trinitarianism in the Old Testament, though agreeing with the Hutchinsonians about the necessity to provide a good unpointed Hebrew text of the Old Testament. ${ }^{17}$ The roots of the clash between Hutchinsonians and Hebraists such as Thomas Sharp and Benjamin Kennicott lie in this difference of intention, which will be discussed further below. An assessment of these confrontations in matters such as biblical exegesis and Hebraic studies will provide a valuable tool for suggesting peculiarly Hutchinsonian traits.

\footnotetext{
${ }^{14}$ Alexander Stopford Catcott, The Supreme and Inferior Elahim (London, 1736).

${ }^{15}$ Ruderman, Jewish Enlightenment, p. 36.

${ }^{16}$ Ruderman, Jewish Enlightenment, p. 40.

${ }^{17}$ For the discussions on providing an authentic text of the Old Testament in the early modern period, see R.A. Muller, 'The Debate over the Vowel Points and the Crisis in Orthodox Hermeneutics', Journal of Medieval and Renaissance Studies 10 (1980): pp. 53-72.
} 
The difference of method between Hutchinsonians and other Hebraists first became apparent with the publication of Catcott's sermon, The Supreme and Inferior Elahim, in which it was made clear that the Hutchinsonians welcomed neither other languages nor pointed Hebrew in elucidating the original text of the Old Testament and its meanings. When Hutchinsonians wrote commentaries on certain words in the Old Testament such as Elahim, traditional Hebraists were alarmed by the way they treated the text. Catcott, in his Sermon, concentrated on the plural and singular usages of the word Elahim, which he referred to as 'supreme and inferior'. When used in the plural, or as Catcott put it, before the Jews had corrupted the text by pointing and reducing it to a singular noun, Elahim signified the Triune God. If one reads the Genesis account, for example, having this in mind, then it would appear Catcott was arguing that the Triune God created the three agents, fire, light and spirit, before the creation of the universe. So the Trinitarian promise in the Old Testament was completely justified. He and his fellow Hutchinsonians insisted that the ways in which Christianity was promised in the Old Testament were simply not negotiable: Hutchinson thought he had reformed the Christian religion and had opened the doors of revelation, not only for the Jews, but for Christians as well, by getting rid of the points that had been inserted by Rabbis to undermine the truth.

Hutchinsonians such as Robert Spearman and Julius Bate argued that Christians should deal with the Hebrew Bible as the written language of God, and they insisted that this language did not involve points. So Hutchinsonians developed a peculiar way of studying Hebrew roots, which considered all possible permutations of a single Hebrew root as related to each other. Hutchinson used Hebrew as a 'code-book containing the secrets of the universe'. In his method, as Katz observes, 'consonants themselves could be constituted into words by the use of any vowels which happened to fit, so as to give the text a variety of meanings' ${ }^{18}$ For example, the words 'gravity' and 'glory' had common roots, which led Hutchinson to argue that it was divine will - exhibiting itself as a material force thereby allowing it to act mechanicallywhich caused objects to fall to the ground, rather than any occult or non-mechanistic force such as the Newtonian concept of gravity. A reviewer of Bate's work The Integrity of the Hebrew Text summarized the basic argument made by him on the use of original Hebrew:

This piece is introduced with a short view of the argument for the genuineness of the books in the Old Testament, which, according to the author, are not only records of our faith, but the repository of all learning, natural and divine, and the evidence for the New Testament. ${ }^{19}$

Another Hutchinsonian, Robert Spearman, argued along similar lines: 'Judaism and Christianity are but different names for one and the same belief, and it was not

\footnotetext{
${ }^{18}$ D.S. Katz, 'The Occult Bible: Hebraic Millenarianism in Eighteenth-Century England', in James E. Force and Richard H. Popkin (Eds.), The Millenarian Turn: Millenarian Contexts of Science, Politics, and everyday Anglo-American Life in the Seventeenth and Eighteenth Centuries (Dortrecht: Kluwer Academic Publishers, 2001), pp. 119-33.

${ }^{19}$ Monthly Review for February, 1755, pp. 81-83.
} 
to the Jews, but to the Gentiles that the gospel brought life and immortality to light'.20

\section{The first phase of the debate}

The main idea of Catcott's sermon centered on the argument about the preexisting covenant between the persons of the Trinity before the universe came into existence. The controversy, however, was going to be centered on the etymology of the word Elahim and its interpretation by Hutchinsonians as 'the Trinity'. The immediate response came from Arthur Bedford, Catcott's predecessor as the vicar of the Temple Church (from which he had resigned in 1713), who published a pamphlet called Observations on a Sermon in the year 1736, immediately following the publication of Catcott's The Supreme and Inferior Elahim. Bedford at the very beginning of the pamphlet stated that when he first read the title page of the sermon by Catcott he thought the word Elohim was written wrongly as Elahim:

But when I found it ninety-three times used in the same Sermon, and always spelt in the same manner, I then perceived it was a mistake of my own, or (pardon the expression) of the learned author. ${ }^{21}$

Bedford was puzzled by the presentation of the word Elahim as the representation of the persons in the Trinity. Bedford argued instead that the word Elohim, as he put it, was 'derived from the Arabick verb Alaha, which signifies to worship religiously, and that it is 'a particle' of the passive voice, and signifies that Being, who alone is religiously to be worshipped'. 22

Hutchinson tended not to approve of the usage of related languages to suggest meanings for the words in Hebrew. In defence of Catcott, Hutchinson, in his remarks on the Observations, accused Bedford of wrongly judging Elahim to be singular and to signify God and God alone, not the Triune existence. ${ }^{23} \mathrm{He}$ bluntly accused Bedford of using Newtonian and Heathen arguments. ${ }^{24}$ Bedford had argued that Oriental languages were the nearest kin to Hebrew, a fact which Hutchinson disputed. This attitude towards other languages was going to be a trademark feature of Hutchinsonians in their later discussions with Hebraists such as Thomas Sharp and Benjamin Kennicott. The Hutchinsonian insistence that the Hebrew of the Old Testament was the original, revealed language and that 'corrupt' languages could not be used to suggest its meaning was essential for their promotion of the Old Testament's Trinitarian promise. Any possible use of other languages would

\footnotetext{
${ }^{20}$ Robert Spearman, An Enquiry after Philosophy and Theology, Tending to show When and Whence Mankind came at the knowledge of these two important points (Edinburgh, 1755), p. 14.

${ }^{21}$ Arthur Bedford, Observations on some Sermons (London, 1741), p. 1.

${ }^{22}$ Ibid., p. 15.

${ }^{23}$ John Hutchinson, Remarks on the Observations (London, 1737), p. 48.

${ }^{24}$ Ibid., p. 4.
} 
undermine the strength of their argument. The highest sin against the Holy Ghost, Hutchinson argued, was to deny Hebrew as the Original Language. ${ }^{25}$

The Hutchinsonian interpretation of the Old Testament was founded in their perception of how theological speculation must be conducted. Those who believed in revealed religion should accordingly have perceived the Trinity, argued Hutchinson. As he addressed Bedford he made it clear from which directions he expected opposition to his interpretation:

Do you profess natural or revealed religion, if revealed, as you strive to evade the Essence in Christ, and mention not the Holy Ghost, you ought to have told us, whether Revelation was given to Men by Angels who draw near to the Divine Majesty, and with whom your brother Mohammed pretended to correspond or by the Spirit that is in your comrades, the Quakers. ${ }^{26}$

Although the backbone of the Catcott controversy was the etymology suggested for the word Elahim by Hutchinsonians - or Elohim as their critics insisted-the controversy, which lasted until the 1760s, displayed a theological tension between Hutchinsonians and non-Hutchinsonians. It was the repeated accusation of Deism, Unitarianism or Arianism by Hutchinson and some of his followers that contributed to the unpopularity of Hutchinsonians.

The impact of Catcott's sermon and the reputation of Hutchinsonian system can be observed by some correspondence concerning the subject and in the periodicals of the time. On 24 January 1738, the Reverend Charles Wheatley wrote to Dr. Rawlinson about Catcott's Elahim. It appears from the letter that there was a certain degree of caution on Wheatley's side about accepting the Hutchinsonian method:

A feeder on Roots; but with him I could heartily take a meal, and twice in my time have had stomach to digest them; but fool as I was, disused myself to them. But I hope they would not have turned my brain, as they seem to have done my fellow collegians. But it is dangerous to enter upon new schemes, when nature is nearer its decline than its spring. ${ }^{27}$

In the 9 October 1736 issue of the Craftsman, Catcott's sermon was mentioned as being 'most remarkable'. The writer of this piece appreciated Catcott's opposition to Jewish pointed texts of the Old Testament, but clearly had some doubts about the value of this Hutchinsonian obsession:

This ancient and Bible way of writing that most significant and revered Hebrew word, savouring too much of the Masora, to please the squeamish palates of the most profound disciples of the self-sufficient J. H[utchinson]. ${ }^{28}$

\footnotetext{
${ }^{25}$ Ibid., p. 40.

${ }^{26}$ Ibid., p. 19.

${ }^{27}$ Quoted in An Annotated Catalogue of the Works of Alexander Stopford Catcott LLB and of his Sons, Bristol Reference Library, Ref. no. 28011. Charles Wheatley was the author of Rational Illustration of the Book of Common Prayer.

${ }^{28}$ Ibid., p. 44.
} 
But there were sympathizers with Catcott too. Thomas Fry, DD, later president of St. John's College, Oxford, wrote to Catcott concerning the publication of Bedford's Observations and assured him that the book was not sent to Oxford for circulation: 'I have perused that scandalous libel published against your sermon... I hear of none that were sent to the Oxford Booksellers'. ${ }^{29}$

In 1738, Bedford published another attack on both Hutchinson and Catcott. ${ }^{30}$ Hutchinson, Bedford argued, had presented himself as the first person, since 'the Inspiration ceased', eight years after the New Testament was finished, to recover the true sense of the Holy Scriptures. ${ }^{31}$ Bedford's arguments came across as direct insults, almost as harsh as Hutchinson's, rather than as substantial criticisms. Catcott's last tract in the debate was a 24-page pamphlet called The State of the Case between Mr. Bedford and Mr. Catcott, in Answer to Mr. Bedford's Examination. ${ }^{32}$ This pamphlet included a summary of the debate and could be regarded as Catcott's last attempt to defend the Hutchinsonian scheme.

In 1739, Daniel Gittins, Rector of South Stoke near Arundel, joined the controversy. ${ }^{33}$ Gittins's pamphlet was basically a defence of the Hutchinsonian method. In February 1738, Bate had introduced Gittins to Catcott as a neighbour of his and an admirer of Hutchinson. ${ }^{34}$ Gittins began corresponding with Catcott 9 months after Bate's introduction. In November 1738, Gittins made it clear that he was going to 'attempt something (however unworthy) by way of answer to this infamous pamphlet', referring to Bedford's An examination. Gittins based his defence of Hutchinsonian concept of Trinity as manifested in the Old Testament on the argument that the Cambridge Platonist, Henry More, had also similar ideas on the subject of Elahim. ${ }^{35}$ More himself had been enthusiastic about the Kabbala and was very much into the reading of Knorr von Rosenroth, whose Kabbala Denudata had been used later by Hutchinson himself as well. ${ }^{36}$

The belief among Hutchinson's followers that they had reformed the religion, or at least continued the Reformation, manifested itself in tracts written during the controversy. Hutchinson in his answer to Bedford stated that: 'The difficulty lies

\footnotetext{
${ }^{29}$ Annotated Catalogue, T. Fry to A.S. Catcott, 29 October 1736. Thomas Fry received his education at the Grammar School in Bristol when A.S. Catcott was the Head Master and became the President of St. John's College, Oxford.

${ }^{30}$ Arthur Bedford, An examination of Mr. Hutchinson's remarks, and Mr. Catcott's answer by the author of the Observations (London, 1738).

${ }^{31}$ Ibid., pp. 4-5.

${ }^{32}$ Alexander Stopford Catcott, The State of the Case between Mr. Bedford and Mr. Catcott, in Answer to Mr. Bedford's Examination (London, 1738).

${ }^{33}$ Daniel Gittins, An Answer to a Pamphlet entitled An Examination of Mr. Hutchinson's Remarks and Mr. Catcott's Answer (London, 1739).

${ }^{34}$ Catcott Correspondence, f. 27, Bate to Catcott, 17 February 1738.

${ }^{35}$ Gittins, An Answer, p. 21. Gittins's reference was to Henry More Theological Works (London, 1708) Book 3. Ch.1.

${ }^{36}$ See D.S. Katz, 'Abendana Brothers and the Christian Hebraists of Seventeenth-Century England', Journal of Ecclesiastical History 40 (1989): 28-52, for a general discussion of the seventeenth-century background to Hebraic studies in England including that at the colleges in Oxford where Hutchinsonians such as Horne and Nayland were educated later.
} 
upon each who reforms, to substitute what is not only better, but what is not liable to any material objection in its stead: When such a one appears, and performs it, it is no wonder, that every dog barks at him, ${ }^{37}$ When Bate published his reply to Bedford in 1739. He argued that the Hutchinsonian method of dealing with the Hebrew of the Old Testament text was revolutionary: 'The Reformation began, and must subsist upon an impartial Search into the Original Scripture'. ${ }^{38}$

In 1741, Daniel Gittins published another pamphlet against Bedford. ${ }^{39}$ His basic argument against Bedford was that the Hutchinsonian concept of Elahim could be derived from the Old Testament, and that Bedford's efforts to confute Hutchinson and Catcott were useless. Bedford in a series of sermons published in 1741 mentioned the Hutchinsonian conception of the Trinity and criticized it for the last time. ${ }^{40}$ Bedford did not agree with the argument of Hutchinsonians that Jews had added the vowel points 'in the second century to obscure the Doctrines of Christianity, particularly of Trinity and Incarnation'. ${ }^{41}$ Bedford was also very much offended by the argument that the only true method of handling the Scripture was that proposed by Hutchinson.

Although Bedford provided an important critique of Hutchinsonianism with his participation in the Catcott controversy, it was the Hebraists, Thomas Sharp and Benjamin Kennicott, who treated the subject specifically as a debate on Hebrew and who investigated the Hutchinsonian method of interpretation in detail.

The deaths of Hutchinson and Catcott put an end to the first phase of the debate. When Thomas Sharp, Archdeacon of Northumberland and Prebendary of Durham, biographer and theological writer, joined the debate, the first phase of the Elahim controversy was well known among intellectual circles. William Warburton discussed the Hutchinsonian method in a letter to Bishop Hurd in 1750. Talking about the people dealing with the unpointed text of the Old Testament, Warburton mentioned Hutchinsonians as a part of this 'fashionable madness': 'The Hutchinsonians pretend that the reason of all the institutions in the Mosaic Law, is to be found in the mysteries of the Hebrew roots'. ${ }^{42}$ Although Warburton's intentions were critical, he was however aware that the Hutchinsonian attitude towards the history of religion that was designed specifically against the Deist literature of the time. The study of Jewish customs and religion was popular among the Deists of the eighteenth century for the purpose of showing that Judaism borrowed most of its aspects from pagan religion. The central idea of the Deists of eighteenth-century England was that natural religion had a universal appeal in contrast to what

\footnotetext{
${ }^{37}$ Hutchinson, Remarks, p. 171.

${ }^{38}$ Julius Bate, The Examiner Examined; or the Examination of the Remarks upon, and Mr. Catcott's Answer to the Observations upon his Sermon considered (London, 1739), p. iv.

${ }^{39}$ Daniel Gittins, Observations on Some Sermons preached at Lady Moyer's Lectures (London, 1741).

${ }^{40}$ Arthur Bedford, A Defence of the Doctrine of the Holy Trinity and the Incarnation of the Son of God, From the Testimony of the Most Ancient Jews in Eight Sermons Preached at the Lady Moyer's Lecture in the Cathedral-Church of St. Paul (London, 1741).

${ }^{41}$ Ibid., p. 56.

${ }^{42}$ William Warburton, Letters from a late eminent Prelate (W.W.) to one of his friends [Bishop Hurd] (London, 1809), pp. 58-9.
} 
revelation had to offer. ${ }^{43}$ In contrast to the Deist view, the Hutchinsonians endeavoured to show that a true believer could read this history of religion properly, showing that Old Testament prophecies led to Trinitarian Christianity and that even the heathen rites and symbols of the deity pointed towards the Trinity. Hebraic studies were part of the plan to strengthen the Christian promise in the Old Testament against the Deists' assault.

\section{The second phase of the debate: Thomas Sharp}

In 1751, Thomas Sharp published a commentary on Catcott's conception of the word Elahim which had touched his own Hebraist concerns. ${ }^{44}$ The British Library manuscript copy of Sharp's pamphlet has an attached letter from Sharp to Spearman written in September 1750 before the publication. Both Sharp and Spearman were natives of Durham and had a long-lasting acquaintance. Sharp's tone in this letter is very respectful; he reminds Spearman of the occasion when the two discussed Catcott's sermon 'in the Winter of 1747' and Spearman's tolerant behaviour towards the criticism Sharp had put forward against Catcott and his Hutchinsonian ideas. Sharp on occasion declared his respect for Hutchinson's 'genius and his application extraordinary'. ${ }^{45}$ However, as an experienced Hebraist himself, Sharp felt the need to clarify some points: 'In the printed controversy that arose from Mr. Catcott's Sermon the merits of the question were not, in my opinion, sufficiently attended to, or fully reached'. 46

Sharp was one of several Hebraists who were alarmed by the way Hutchinsonians treated the text in their commentary on certain words such as Elahim in the Old Testament. The use of other languages was not accepted by Hutchinsonians, and the pointed text of the Old Testament was not allowed as evidence for the interpretation of the originally unpointed words. As far as Sharp was concerned, the Hutchinsonian method was stretched too far to justify their arguments on the Trinitarian promise in the Old Testament.

Sharp's criticisms were immediately followed by a Hutchinsonian response. With this second phase of the debate, we see different persons joining the pamphlet war against Sharp. The first reply came from David Aboab, a Venetian Jew later converted to Christianity, and a Hutchinsonian. ${ }^{47}$ Julius Bate and Benjamin Holloway followed Aboab. ${ }^{48}$ Holloway, with his customary claim to an independent position, did not become very involved with Hutchinsonian terminology, but found a way to criticize Sharp through his studies in Oriental languages. As a reaction to

\footnotetext{
${ }^{43}$ Israel, Radical Enlightenment, p. 604, 620.

${ }^{44}$ Thomas Sharp, Two Dissertations concerning the Meaning of the Hebrew words Elohim and Berith, occasioned by some notions lately advanced in Relation to them (London, 1751).

${ }^{45}$ British Library Add MS. 4369, ff. 2-14, Thomas Sharp to Robert Spearman, September 1750.

${ }^{46}$ Ibid.

${ }^{47}$ David Aboab, Remarks on Dr. Sharp's Two Dissertations (London, 1751).

${ }^{48}$ Julius Bate, The Scripture Meaning of Aleim and Berith (London, 1751); Benjamin Holloway, Remarks on Dr. Sharp's Pieces on the Words Elohim and Berith (Oxford, 1751).
} 
Sharp's comparison of Hebrew with Arabic, concluding that the word Elahim had a singular root implying one God, Holloway argued disapprovingly: 'I hear this language, made at every turn, sister to the Hebrew, yes, often, it's mother, and preferred before it'. ${ }^{49}$ Bate, in his attack, criticized Sharp's questioning of Hebrew's being the most ancient and holy tongue. The Hutchinsonian assertion that Hebrew was the tongue of God would remain as a source of their argument all through the debate and was stressed by them at almost every turn.

The only support for Sharp came from George Kalmar, whose three pamphlets in this controversy were directed against Julius Bate, Benjamin Holloway and David Aboab. ${ }^{50}$ Kalmar, like Sharp, questioned the Hutchinsonians' certainty that the Hebrew Old Testament was the original and unchanging language of revelation:

Can he [Holloway] tell me then what language (Abraham), Moses and David talked and wrote in? Language which he thinks of Paradise always? Or, if they used sometimes Chaldee or Syriac, \&c; how can he tell me which is this or that ${ }^{51}$

The phase of the debate involving Sharp attracted much publicity. Many issues of the Monthly Review and Gentleman's Magazine were full of pro- and antiHutchinsonian writings on the subject. ${ }^{52}$ David Levi (1740-99), a Jewish Hebrew scholar, treated the controversy in the introduction to his work on Hebrew, Lingua Sacra. He introduced the subject by giving references to the participants of the debate. Levi, through careful research, compiled a list of those persons who had worked on the 'Christian interpretation of Elohim as alluding to Trinity'. 53 Among 'the English Clerics', he included Dr. Matthew Henry (1662-1714), author of the sixvolume Exposition of the Old and New Testaments, and John Gill (1697-1771). After a long assessment of the debate between the Hutchinsonians and Sharp, Levi concluded his survey of the subject with his own point of view:

I must freely confess my astonishment...in thus building the doctrine of Trinity upon so slight a foundation: for allowing the noun Eloeheem to be plural, even when applied to the Deity, yet, what proof hath he produced, that plurality implies Trinity and no more. I may as well advance, that it implies two, two hundred, or two thousand, and so on ad infinitum. ${ }^{54}$

\footnotetext{
${ }^{49}$ Holloway, Remarks, p. 33.

${ }^{50}$ George Kalmar, Mr. Bate's answer to Sharp's two Dissertations answered (London, 1751); A short Reply to Mr. Holloway's Remarks on Dr. Sharp's two Dissertations (London, 1751); Censurer Censured: Or a defence of Dr. Sharp's two Dissertations \&c. Being a Reply to Mr. Aboab's Remarks (London, 1751).

${ }^{51}$ Kalmar, Short Reply, pp. 16-17.

${ }^{52}$ Gentleman's Magazine: 'Mr. Moody's treatise on Elohim and Berith', May 1752, p. 205; 'Objections against the Hutchinsonian account of the Cherubim', June 1752, p. 259; 'Objections to Hutchinsonians', July 1752, p. 316; 'Letter in defense of the Hutchinsonian sense of Cherubim', August 1752, p. 354; 'Further remarks on the Hutchinsonians', September 1752, pp. 415-16; 'Hutchinsonian opinion of Goodness, Intellect and Power defended', November 1752, p. 52; 'Candidus on the Hutchinsonian controversy', December 1752, pp. 549-50.

${ }^{53}$ Ruderman, Jewish Enlightenment, p. 71.

${ }^{54}$ David Levi, Lingua Sacra in Three Parts (London, 1785-87), Part II, vol. 1, entry 'Elohea, God' (no pagination).
} 
Although Levi expressed his disapproval of Hutchinson's method, he was careful not to get involved in controversy with the Hutchinsonians. Sharp showed his regret at getting into the polemical debate over Elahim as early as 1750 in a letter to a friend:

I shall scarcely surprise you with telling you...that I have been fool enough to risk my Hebrew scraps amongst the Hutchinsonians. Indeed I have little to say for myself, but that I was persuaded to do so by some people much wiser than myself in those matters. ${ }^{55}$

The Hutchinsonian response to Sharp came also from a newly flourishing Oxford community of followers. Walter Hodges, one of the first Oxonian followers of Hutchinson, published his first assessment of the subject in $1752 .{ }^{56}$ However, in another letter written in 1754, Sharp wanted to explain his reasons for engaging in such a confrontation with the Hutchinsonians:

I should not have given myself any trouble, even about Mr. Hutchinson's, if he and his followers had not set it up as the first article in revealed religion, spoke of it as indisputably proved, and reflected on the whole Christian world for not acknowledging it sooner. $^{57}$

As much as he was disturbed by the Hutchinsonian claim to the monopoly of true method, Sharp did not totally withdraw from the arena. In 1755, he published another pamphlet on Hebrew ${ }^{58}$ and had a reply from the Hutchinsonians. ${ }^{59}$ In his correspondence, Sharp expressed his disappointment with Hutchinsonian strictness in dealing with unadorned, unpointed Hebrew. As to the interpretation of the words, Sharp openly stated that: 'I wish we had better authority for it than the Jewish writers'. ${ }^{60}$ In the absence of such authority, he was prepared to accept that there was room for doubt: 'Conjectures, when evidence is wanting, are always acceptable'. ${ }^{61}$ This, obviously, was not compatible with the Hutchinsonian refusal to accept rational debate in matters of biblical exegesis.

Julius Bate in his reply to Sharp made it quite clear what kind of offence those who criticized Hutchinson were guilty of. His words are representative of the dogmatic

\footnotetext{
${ }^{55}$ John Nichols, Literary Anecdotes of the Eighteenth Century (London: Nichols, Son and Bentley, 1812), vol. 4, p. 352.

${ }^{56}$ Walter Hodges, The Christian Plan, exhibited in the interpretation of Elohim: with Observations upon a few other matters and expressions relative to the same subject (Oxford, 1752).

${ }^{57}$ Nichols, Literary Anecdotes, from Thomas Sharp to Zechariah Grey, Durham, 27 December 1754.

${ }^{58}$ Thomas Sharp, Discourses touching the Antiquity of the Hebrew Tongue and Character (London, 1755).

${ }^{59}$ Walter Hodges, Reflections (Oxford, 1755).

${ }^{60}$ Nichols, Literary Anecdotes, vol. 4, p. 352.

${ }^{61}$ Ibid.
} 
Hutchinsonian attitude:

It is easy now to see the source of the opposition Mr. Hutchinson has met with on this head. Jews, Arians and Socinians, deny a Trinity, the Divinity of Christ. ${ }^{62}$

Benjamin Kennicott was also to complain of being similarly accused because his method in dealing with the Old Testament text differed from that of the Hutchinsonians.

\section{The Third Phase: Benjamin Kennicott}

What gave the Elahim controversy its cutting edge was the complete intolerance of their opponents shown by the Hutchinsonians. In the name of reforming the religion, the Hutchinsonians accused various thinkers of being either Arian, Deist, or at times infidels. Eventually, this was going to change and the later eighteenth century was going to witness a Hutchinsonian agenda which was basically more moderate, aimed towards uniting orthodoxy, rather than at confronting everybody, in order to get their point across. George Horne is a name to mention here, pioneering this later moderation. However, the years of the Elahim controversy represented the period when Hutchinsonian intolerance was still in full flood.

The biggest clash came with the Oxford Hebraist, Benjamin Kennicott, who had set himself the task of preparing the best possible unpointed text of the Old Testament. Kennicott tried to reclaim the Hebrew text for Christians by liberating it from the unchallenged authorities of the 'rabbies' by a systematic collection of Hebrew manuscripts and a comprehensive study of ancient translations. Kennicott compared different manuscripts of the Hebrew texts in a scholarly fashion. After tracing 615 Hebrew manuscripts and 16 manuscripts of the Samaritan Pentateuch, he began publishing his version in 1776 (The Vetus Testamentum Hebraicum cum Variis Lectionibus, 1776-80).

The Hutchinsonians were Kennicott's most enthusiastic antagonists. The aims of the two opposing sides were on some points similar, i.e. providing an unpointed Hebrew text of the Old Testament. The argument of the Hutchinsonians was that:

Christians should confront the Hebrew Bible directly as the continuing revelation of God, unmediated by Jewish interpretations of Scripture, and divested of the vowel points invented by modern Jews to mislead Christians in understanding their own sacred scriptures. ${ }^{63}$

Kennicott would probably not have disagreed with this. However, he certainly did disagree with the enforcement of an explicitly Trinitarian agenda on to the text by Hutchinsonians and with the Hutchinsonian rejection of any idea that theer might be variant unpointed texts.

Julius Bate's The Integrity of the Hebrew Text, published in London in 1754, is a fine example of the Hutchinsonian approach to Kennicott's project. Bate published

\footnotetext{
${ }^{62}$ Julius Bate, A Reply to Dr. Sharp's Review and Defence of his Dissertations on the Scripture Meaning of Aleim and Berith (London, 1755), p. 161.

${ }^{63}$ Ibid., p. 34.
} 
several works in defence of Hutchinsonianism, including Critica Hebraea or a Hebrew-English Dictionary without Points, which appeared in 1767. Bate opened his pamphlet against Kennicott by

Railing against his temerity of correcting the sacred pages of Scripture with the same 'vague and licentious spirit of criticism' that has plagued the new readers of Shakespeare and Pope. ${ }^{64}$

Bate was not the only Hutchinsonian who felt compelled to ravage Kennicott. Fowler Comings in 1753 attacked Kennicott on the same grounds as Bate did. ${ }^{65}$

The essence of the Hutchinsonian charge against Kennicott was that, in playing fast and loose with the letter the way, as the Hutchinsonians accused Kennicott of doing, destroyed the possibility of a spiritual interpretation as far as Hutchinsonians were concerned. However, the form of the criticism that was made upset Kennicott a great deal. He published $A$ Word to the Hutchinsonians in 1756. Kennicott pointed out the danger of the Hutchinsonian claim to be reformers of the religion. He also complained that the Hutchinsonians insulted whoever criticized them with Arianism or some other form of anti-Trinitarianism. He complained that Hutchinsonians made 'words signify what they please... with all such meanings as were never meant'. ${ }^{66}$ Unfortunately, whoever stood in the Hutchinsonians' way had the misfortune of being accused of contributing to the rise of infidelity. Kennicott had his first reply from a young and still relatively intolerant Horne, in 1756. It was in direct opposition to Kennicott's claim to have assembled the genuine Hebrew text of the Old Testament. ${ }^{67}$ Horne published his second attack against Kennicott's design in 1760 and argued that his method of dealing with the Old Testament would open the door to scepticism and infidelity 'which all the art of man will never be able to shut again'. ${ }^{68}$ Ruderman's suggestion as to the offence Kennicott caused to Horne and other Hutchinsonians is valid: 'By destabilizing the text, Kennicott had undermined the force of their unique exegesis that rested on the assumption that the Hebrew text was fixed and standardized' ${ }^{69}$ In the Hutchinsonian view, Kennicott was guilty of undermining the revealed language and the more he did so, by preoccupying himself with establishing the letter from variant texts, the further he abandoned the truth of the religion. In a proper Pauline fashion, Hutchinsonians argued that what gave life to the text was its spirit and at the heart of the matter lay the Trinitarian promise.

The debate between the Hutchinsonians and Benjamin Kennicott was well publicized. The coverage given to the controversy by the Gentleman's Magazine

\footnotetext{
${ }^{64}$ Bate, Integrity of the Hebrew Text, p. VI.

${ }^{65}$ Fowler Comings, The Printed Hebrew Text of the Old Testament Vindicated. An Answer to Mr. Kennicott's Dissertation in two parts (Oxford, 1753).

${ }^{66}$ Benjamin Kennicott, $A$ Word to the Hutchinsonians (London, 1756), p. 5.

${ }^{67}$ George Horne, An Apology for certain gentlemen in the University of Oxford, aspersed in a late anonymous pamphlet entitled 'A Word to the Hutchinsonians' (Oxford, 1756). The second edition appeared in 1799 .

${ }^{68}$ George Horne, A View of Mr. Kennicott's Method of Correcting the Hebrew Text (London, 1760), p. 24.

${ }^{69}$ Ruderman, Jewish Enlightenment, p. 35.
} 
between 1751 and 1753 demonstrates the interest shown by the intellectual circles of the time in the Hutchinsonian movement and the debate. There were a considerable number of non-Hutchinsonians who felt compelled to publish on the subject. One of them was Anselm Bayly. His criticism of Kennicott's project and appreciation of the Hutchinsonian denial of 'pointing' became apparent when he published A Plain and Complete Grammar of the Hebrew Language With and Without Points in 1773. Apart from his criticism of Kennicott, his way of introducing John Hutchinson to the reader is quite telling:

He opposed the points with greater warmth than Capellus and stood up for the correctness of the Hebrew writings, with more zeal than even Buxtorf...[He] proposed to open a wider path to the Hebrew; he professed to enter into the language more profoundly than any that preceded him, with an eye to philosophy as well as divinity. ${ }^{70}$

The reputation of Hutchinsonians was linked primarily to their biblical exegesis based on the unpointed Hebrew text of the Old Testament. The spread of Hutchinsonian ideas into Oxford was partly due to the 1748 edition of Hutchinson's works, but also partly related to the publicity created by the long-lasting Elahim debate among intellectual circles of the time.

The confrontation of an orthodox movement such as Hutchinsonianism with the proponents of natural religion or with anyone who threw doubt on the certainty and completeness of the revealed text represented a clash of forces within the Enlightenment, one fideistic, one rationalist, yet both part of the eighteenth-century intellectual agenda. One thing to stress is that different sections of eighteenth-century thought, rationalist and fideists alike, found something to argue about in this debate. The preoccupation with Judaism and its text in this period is an invitation to historians of the eighteenth century to reconsider the parameters of the Enlightenment paradigm.

The eighteenth-century Hebraists - Christian and Jewish alike-found it difficult to accept the Hutchinsonian dogmatic insistence on the self-sufficiency of the unpointed Hebrew. The Hutchinsonian approach of using and interpreting an untainted Old Testament text in unpointed Hebrew triumphed as the basis. However, comparative linguistics as a method of establishing this text, as promoted by Kennicott and Sharp, in the end triumphed over the Hutchinsonian, spiritual method of interpreting what was to them a fixed and certain unpointed text. The direction that Hebraic studies was taking by the 1760s pointed towards a more comparative approach, such as that of Kennicott, where not only a variety of manuscripts of the Old Testament were examined for a more accurate account, but also comparison was to be made with other Oriental languages such as Arabic in order to ascertain meanings.

By 1780s, Hebraic studies ceased to be the main tool for the Hutchinsonian defence of the Trinity. Essentially, they had lost that argument. Hutchinsonian intolerance, which must take part of the blame in their demise, was to go through

\footnotetext{
${ }^{70}$ Quoted in Ruderman, Jewish Enlightenment, p. 43.
} 
remarkable change in the following years. George Horne can be regarded as the man who tried most to moderate the Hutchinsonian profile. William Jones of Nayland's letter to his biographer William Stevens testifies to this notable change. Jones of Nayland stated that Horne wrote against Kennicott's plan 'without any fear or reserve', but went on to explain that 'from the moderation and farther experience of both parties,... though the acquaintance began in hostility, they at length contracted a friendship'. ${ }^{71}$ Jones of Nayland himself being Horne's biographer, knew about the later Horne and his feelings then about Hutchinsonian militancy. Horne, on one occasion stated that:

Mankind are tired and sick (I am sure I am one) with the fruitless squabbles and altercations about etymologies and particularities. In the meantime, the great plan of philosophy and theology, that must instruct and edify, lies dormant. ${ }^{72}$

\section{Acknowledgements}

The author would like to thank the Turkish Academy of Sciences for supporting her research in the UK. This made it possible for her to attend the Conference of the British Society for Eighteenth-Century Studies held at St. Hugh's College, Oxford (3-5 January 2003), where parts of this paper were read. The author would also like to thank Paul Latimer and C.D.A. Leighton for their constructive criticisms.

\footnotetext{
${ }^{71}$ William Stevens ed., Collected Works of William Jones of Nayland (London, 1801): vol. 12, p. xi.

${ }^{72}$ George Horne, quoted in Jones of Nayland, Memoirs, pp. 55-56.
} 